\title{
Pengaruh Resiliensi dan Empati terhadap Gejala Depresi pada Remaja
}

\author{
Endah Mujahidah', Ratih Arruum Listiyandini ${ }^{2}$ \\ 1,2 Fakultas Psikologi, Universitas YARSI, Jakarta \\ email: endah_mujahidah@yahoo.com,ratih.arruum@gmail.com
}

\begin{abstract}
Abstrak
Remaja merupakan masa kritis karena dihadapkan pada berbagai tugas perkembangan yang merupakan transisi menuju dewasa. Kegagalan remaja dalam mencapai tugas perkembangan membuat remaja rentan mengalami gangguan psikologis seperti depresi. Penelitian ini bertujuan untuk mengetahui sejauh mana resiliensi dan empati berpengaruh terhadap gejala depresi pada remaja. Penelitian merupakan penelitian kuantitatif eksplanatori dengan desain cross-sectional. Pengukuran dilakukan dengan menggunakan adaptasi skala Center for Epidemiologic Studies Depression Scale Revised-10 (CESDR-10) untuk mengukur depresi, adaptasi skala resiliensi Connor \& Davidson, serta Basic Empathy Scale (BES) dari Jollife \& Farrington. Sampel yang digunakan berjumlah 230 orang remaja berusia 12-20 tahun berdomisili di Jakarta yang diambil dengan teknik sampling convenience sampling. Hasil analisis statistik menggunakan uji regresi sederhana menunjukkan bahwa resiliensi berpengaruh secara bermakna terhadap gejala depresi dengan sumbangan efektif sebesar 1,8\%. Empati juga memiliki pengaruh terhadap gejala depresi secara bermakna dengan kontribusi efektif sebesar $2 \%$. Saat dilakukan uji regresi berganda, yaitu resiliensi dan empati menjadi variabel prediktor secara bersama-sama, maka ditemukan bahwa empati dan resiliensi dapat mempengaruhi kemunculan gejala depresi secara bermakna dengan total sumbangan efektif sebesar $5,5 \%$. Dalam hal ini, tingginya empati berpengaruh terhadap tingginya gejala depresi, namun sebaliknya, resiliensi yang tinggi berpengaruh terhadap gejala depresi yang lebih rendah. Dengan demikian, dapat disimpulkan bahwa resiliensi dan empati berpengaruh signifikan terhadap gejala depresi pada remaja.
\end{abstract}

Kata kunci: depresi, resiliensi, empati, remaja.

\section{The Influence of Resilience and Empathy toward Depression of Adolescents}

\begin{abstract}
Adolescence is critical period because they are faced with a variety of developmental tasks which is transitional process for being an adult. The failure in achieving the developmental tasks can make adolescents susceptible to psychological disorders, such as depression. This study aimed to determine whether resilience and empathy can influence the depression symptoms among adolescents. This study was using explanatory quantitative approach with cross-sectional design. Measurment was taken using adapted scale of Center for Epidemiologic Studies Depression Scale Revised-10 (CESDR-10) for measure depression, adapted resilience scale from Connor \& Davidson, and the Basic Empathy Scale (BES) from Jollife \& Farrington. The sample was 230 adolescents aged 12-20 years from Jakarta who were taken using convenience sampling technique. Statistical analysis using simple linear regression indicated that resilience has significant influence on the level of depression symptoms with $1.8 \%$ effective contribution. Empathy can also influences the level of depression symptoms significantly with $2 \%$ effective contribution. By using multiple linear regression, it found that simultaneously resilience and empathy can influence the level of depression symptoms, with $5,5 \%$ total effective contribution. In this case, while higher empathy followed by higher depression symptoms, contradictory, the higher of resilience will be followed by lower depression symptoms. Hence, it can be concluded that resilience and empathy can significantly influence depression symptoms among adolescents.
\end{abstract}

Keywords: depression; resilience; empathy; adolescent 


\section{Pendahuluan}

Masa remaja merupakan masa transisi dan kritis bagi perkembangan seseorang (Papalia, Olds \& Feldman, 2009; Batubara, 2010; Shaffer, Kipp, Wood, \& Willoughby, 2013). Pada masa remaja, terjadi berbagai perubahan yang cepat, baik perubahan fisik, kognitif bahkan psikososial (Papalia, Olds \& Feldman, 2009; Hilt, Hanson, \& Pollak, 2011). Sejalan dengan perubahan-perubahan yang terjadi, remaja juga dihadapkan pada tugastugas yang berbeda dibandingkan dengan masa kanak-kanak (Retnowati, 2001). Tugas perkembangan tersebut di antaranya menjalin hubungan sosial yang lebih matang dengan teman sebaya, mengembangkan keterampilan komunikasi interpersonal serta mencapai kemandirian emosional dari orangtua dan figur otoritas (Choudhury, Blakemore \& Charman, 2006; Kenny, Dooley, \& Fitzgerald, 2013). Tugas-tugas perkembangan di atas merupakan kunci dasar bagi perkembangan selanjutnya. Apabila tugas tersebut berhasil diselesaikan akan membawa dampak positif terhadap individu berupa kebahagiaan dan keberhasilan penyelesaian pada tugas-tugas berikutnya. Di sisi lain, apabila individu mengalami kegagalan, maka akan berdampak pada ketidakbahagiaan, mengalami gangguan psikososial, ketidakstabilan emosi, bahkan pada akhirnya dapat memunculkan gangguan depresi (Arnett, 1999; Steinberg, 2009; Cunningham dalam Utari \& Retnowati, 2011; Erikson dalam Anindyajati 2013).

Dalam DSM V, American Psychiatric Association (2013) mendefinisikan depresi sebagai gangguan suasana perasaan dimana seseorang diliputi perasaan depresi seperti sedih, hampa, dan putus asa atau kehilangan minat dalam berbagai aktivitas selama dua minggu atau lebih. Gangguan depresi dinilai menjadi masalah serius yang sering terjadi pada masa remaja (Keenan \& Hipwell, 2005; Papalia, Olds \& Feldman, 2009; Hashmi, 2013; Utari \&Retnowati, 2011). Hasil penelitian menunjukkan bahwa fenomena depresi pada dasarnya meningkat secara signifikan selama masa remaja, dan diperkiraan prevalensi depresi berat selama masa remaja mencapai 14-20\% (Kessler, Avenevoli, \& Merikangas, 2001). Meski demikian, depresi pada remaja seringkali tidak mendapat perhatian dan pertolongan yang memadai atau bahkan tidak terdeteksi oleh keluarga dan lingkungan sekitarnya (Son \& Kirchner 2000). Tandatanda gangguan depresi pada remaja sering dipandang sebagai gejolak emosional yang wajar terjadi pada tahap perkembangannya. Padahal, depresi yang tidak diatasi pada masa remaja akan berdampak negatif pada beberapa hal dalam kehidupan sekolah, keluarga, kesulitan hubungan sosial serta kesehatan mental di masa dewasa (Seimeon dalam Milin, Walker, \& Chow, 2003; Thorsteinsson, Ryan, \& Sveinbjornsdottir, 2013), seperti perilaku bunuh diri, penggunaan narkoba, penurunan prestasi belajar, perilaku agresif dan perilaku merusak lainnya (Aditomo \& Retnowati, 2004).

Berdasarkan paparan terkait dampak negatif dari depresi terhadap kehidupan remaja, membuat remaja perlu memiliki kemampuan untuk menghadapi berbagai kesulitan. Kualitas pribadi yang memungkinkan seseorang untuk berkembang dalam menghadapi kesulitan disebut sebagai resiliensi (Connor \& Davidson, 2003). Ketika remaja memiliki kemampuan resiliensi, maka remaja mampu mengatasi tekanan kehidupan yang dihadapinya sehari-hari (Connor \& Davidson, 2003; Isaacson dalam Everall, Altrows \& Paulson, 2006), serta dapat mengatasi masalah dalam masa perkembangannya (Crump, et.al. 2015). Oleh karena itu, dengan adanya resiliensi, remaja akan terbantu dalam meningkatkan faktor pelindung untuk menghadapi suatu tantangan dan meminimalkan dampak dari faktor resiko seperti depresi (Wilks, 2008; Pinquart, 2009). Hasil penelitian menunjukkan bahwa resiliensi menjadi mediator dan prediktor tingkat keparahan depresi remaja dan mahasiswa (Ziaian, et.al. 2011; Loh, Schutte \& Thorsteinsson, 2013; Camardese, et.al., 2012; Hjemdal, et.al. 2015). Individu dengan resiliensi yang baik, memiliki tingkat keparahan depresi yang lebih rendah. Begitu juga sebaliknya, individu dengan resiliensi yang rendah, terutama dalam dimensi kepercayaan diri dan optimisme, akan memiliki tingkat keparahan yang tinggi dalam hal depresi (Bitsika, Sharpley, \& Peters, 2010).

Selain resiliensi, hal lain yang perlu dimiliki remaja untuk mencegah kemunculan depresi adalah kemampuan sosial mereka. Kemampuan sosial dinilai penting bagi re- 
maja mengingat bahwa salah satu tugas perkembangan remaja adalah membangun hubungan sosial dengan orang lain (Choudhury, Blakemore, \& Charman, 2006). Keberhasilan seseorang dalam menjalin hubungan sosial dengan orang lain dapat dilihat dari kemampuannya dalam memahami kondisi dan perasaan orang lain. Kemampuan untuk memahami kondisi dan ikut merasakan sebagian keadaan emosional orang lain disebut sebagai empati (Jolliffe \& Farrington, 2006). Terdapat dua aspek dalam empati, yaitu komponen afektif dan kognitif. Empati afektif merupakan aspek empati yang menggambarkan proses saat emosi seseorang muncul, baik sadar, maupun tidak sadar karena adanya persepsi akan keadaan internal di dalam diri orang lain, sedangkan komponen empati kognitif menggambarkan pemahaman secara intelektual mengenai perspektif orang lain dengan tepat (Jollife \& Farrington, 2006).

Individu yang memiliki empati, akan lebih terampil dalam menginterpretasikan bahasa-bahasa nonverbal yang ditunjukkan oleh orang lain, seperti ekspresi wajah, intonasi suara, bahasa tubuh serta mampu menangkap apa yang dipikirkan dan dirasakan orang lain (Reivich \& Shatte, 2002). Kemampuan untuk berbagi perasaan orang lain dan menempatkan diri dalam perspektif orang itu sangat penting bagi munculnya kompetensi interpersonal yang baik, yang pada akhirnya, meningkatkan kesejahteraan psikologis yang lebih positif (Chow, Ruhl, \& Buhrmester, 2013). Oleh karena itu, empati membantu untuk terciptanya hubungan sosial dan relasi yang lebih positif, sukses dan kompeten pada pertemanan remaja (Dixon \& Moore, 1990; Eisenberg, 2000; Reivich \& Shatte, 2002; Baron-Cohen \& Wheelwright, 2004; Berndt dalam Smith \& Rose, 2011). Hasil penelitian sebelumnya juga menemukan bahwa kemampuan remaja akhir dalam memahami sinyal-sinyal sosial di lingkungan dapat membantunya lebih resilien saat memasuki masa transisi kehidupan (Andriani \& Listiyandini, 2017). Empati menjadi bekal akan hubungan yang sukses, dan hubungan yang sukses akan membentuk adanya pertemanan yang saling mendukung satu sama lain, sehingga menjadi faktor pelindung terhadap kemunculan depresi (Egbert, Miraldi, \& Murniadi, 2014).
Hasil penelitian Donges, et.al. (2005) menunjukkan bahwa pasien dengan depresi parah menunjukkan kesadaran yang utuh dari emosi mereka sendiri, tetapi kurang akan kemampuan memahami emosi orang lain (empati), sehingga penurunan kemampuan memahami orang lain ini berhubungan juga dengan adanya gejala depresi. Penelitian lain menemukan bahwa empati berkorelasi negatif dengan depresi pada kedua aspek dari empati, yaitu aspek afektif dan kognitif (Cusi, MacQueen, Spreng \& McKinnon, 2011). Hasil penelitian lainnya menunjukkan bahwa depresi terkait dengan empati seseorang hanya dalam aspek kognitif, yaitu perspective taking dan tidak terkait dengan aspek afektif (Schreiter, Pijnenborga, \& Rota, 2013).

Berdasarkan pemaparan di atas, telah ditemukan bahwa terdapat hubungan yang bersifat negatif antara depresi dengan resiliensi maupun empati pada remaja. Namun demikian, penelitian-penelitian sebelumnya hanya menguji hubungan kedua variabel tersebut dan belum meneliti mengenai pola keterkaitan serta peranan antar keduanya. Oleh karena itu, peneliti tertarik untuk mengkaji kembali mengenai peranan resiliensi dan empati terhadap depresi pada remaja.

Berdasarkan hal itu, peneliti tertarik melakukan studi mengenai peran resiliensi dan empati terhadap depresi pada remaja. Peneliti memiliki tiga hipotesis di dalam penelitian ini, yaitu bahwa: 1) terdapat pengaruh resiliensi yang signifikan dalam menjelaskan tingkat gejala depresi pada remaja, 2) terdapat pengaruh empati yang signifikan dalam menjelaskan tingkat gejala depresi pada remaja, dan 3) secara bersama-sama, resiliensi dan empati berpengaruh signifikan dalam menjelaskan tingkat gejala depresi pada remaja. Penelitian ini diharapkan dapat menjadi salah satu sarana pengembangan ilmu psikologi, terutama terkait dengan tema resiliensi, empati, dan depresi. Selain itu, penelitian ini diharapkan dapat memberikan informasi bagi remaja mengenai aspek yang dapat mencegah depresi, serta menjadi informasi juga bagi berbagai pihak yang ingin merencanakan strategi intervensi untuk mencegah depresi dan meningkatkan kesehatan mental remaja. 


\section{Metode}

Desain Penelitian dan Identifikasi Variabel

Penelitian ini menggunakan pendekatan kuantitatif dengan disain penelitian asosiatif dan cross-sectional. Terdapat tiga variabel dalam penelitian ini, yaitu resiliensi dan empati sebagai variabel prediktor (variabel bebas) dan depresi sebagai variabel kriteria (variabel terikat).

\section{Subjek}

Partisipan dalam penelitian ini ditentukan dengan kriteria remaja berusia 12-20 tahun yang bertempat tinggal di Jakarta serta minimal lulus Sekolah Dasar. Partisipan diambil dengan menggunakan non-probability sampling dengan teknik convenience sampling. Teknik convenience sampling dipilih karena mengingat sifat studi yang bersifat eksploratif dan tidak ditemukannya data akurat mengenai persebaran remaja di Jakarta. Belum ada hasil riset yang menunjukkan mengenai prevalensi depresi pada populasi remaja secara khusus di seluruh Indonesia. Namun demikian, hasil Riset Kesehatan
Dasar (Riskesdas) tahun 2013 menunjukkan bahwa prevalensi gangguan mental-emosional, termasuk depresi pada individu usia 15 tahun ke atas di DKI Jakarta adalah sebesar 5.7 \% (Balitbang Kementerian Kesehatan, 2013). Sebagai salah satu kota besar dengan penduduk terpadat yaitu berkisar 10 juta jiwa (Badan Pusat Statistik, 2017), maka jumlah orang yang diperkirakan memiliki gangguan mental-emosional di DKI Jakarta, termasuk depresi adalah kurang lebih 500 hingga 600 ribu orang.

Berdasarkan persebaran data dari 230 remaja yang berpartisipasi dalam penelitian, $55.2 \%$ adalah perempuan dan ditemukan rata-rata usia partisipan $\mathrm{M}=15.76(\mathrm{SD}=1.71)$. Sebanyak $92.6 \%$ beragama Islam sisanya beragama Nasrani, dan $41.3 \%$ partisipan mengidentifikasikan diri beretnis Jawa, sisanya adalah Betawi, Sunda, Minang, Ambon, Cina, dan lainnya. Berdasarkan data pengeluaran orangtua, sebagian besar pengeluaran orangtua partisipan berada pada rentang 1.000.001-3.000.000 per bulan (47.8\%). Berikut adalah tabel yang menggambarkan profil demografis partisipan:

Tabel 1. Persebaran Profil Demografis Partisipan

\begin{tabular}{lll}
\hline Kategori & Jumlah (N) & Persentase (\%) \\
\hline Jenis Kelamin & & \\
Laki-laki & 102 & $44.3 \%$ \\
Perempuan & 127 & $55.2 \%$ \\
Usia & $(\mathrm{M}=15,76 ;$ SD & $1,716)$ \\
Remaja Awal (11-14 tahun) & 42 & $18.3 \%$ \\
Remaja Tengah (15-17 tahun) & 163 & $70.9 \%$ \\
Remaja Akhir (18-21 tahun) & 25 & $10.9 \%$ \\
Agama & & \\
Islam & 213 & $92.6 \%$ \\
Kristen & 16 & $7.0 \%$ \\
Hindu & 1 & $0.4 \%$ \\
Suku & & \\
Betawi & 53 & $23.0 \%$ \\
Jawa & 95 & $41.3 \%$ \\
Sunda & 37 & $16,1 \%$ \\
Batak & 9 & $3,9 \%$ \\
Minang & 7 & $3,0 \%$ \\
Bugis & 3 & $1,3 \%$ \\
Lainnya & 23 & $10,0 \%$ \\
Tidak Mengisi & 3 & $1,3 \%$ \\
Pengeluaran Orangtua perbulan & & \\
<1.000.000 & 21 & $9,1 \%$ \\
1.000.001-3.000.000 & 110 & $47,8 \%$ \\
3.000.001-5.000.000 & 44 & $19,1 \%$ \\
5.000.001-7.000.000 & 19 & $8,3 \%$ \\
>7.000.000 & 22 & $9,6 \%$ \\
Tidak Mengisi & 14 & $6,1 \%$ \\
Jumlah & 230 & \\
\hline
\end{tabular}




\section{Pengukuran}

Alat ukur yang digunakan untuk mengukur variabel dalam penelitian ini adalah Center for Epidemiologic Studies Depression Scale Revised-10 (CESDR-10) dari Haroz, Ybarra, dan Eaton (2014) untuk mengukur gejala depresi, skala resiliensi dari Connor dan Davidson (2003) untuk mengukur resiliensi, serta Basic Empathy Scale (BES) dari Jolliffe dan Farrington (2006) mengukur empati. Sebelum dilakukan pengambilan data, seluruh skala telah melalui proses adaptasi bahasa melalui translasi dari Bahasa Inggris ke Bahasa Indonesia, back-translate, serta uji keterbacaaan. Kemudian, uji coba skala dilakukan terhadap 80 orang remaja untuk mengetahui validitas dan reliabilitas skala.

CESDR-10 merupakan alat ukur yang dikembangkan oleh yang terdiri dari 10 aitem dan mengukur beberapa subskala dari gejala depresi, diantaranya sadness (Dysphoria), loss of interest (Anhedonia), appetite, sleep, thinking/ concentration, guilt, (worthlessness), tired (fatigue), movement (agitation), suicidal ideation dan irritable dengan menggunakan skala likert dengan empat pilihan jawaban 0 untuk sama sekali tidak atau kurang dari 1 hari dalam 2 minggu terakhir, hingga skor 3 untuk 5-7 hari dan hampir setiap hari selama 2 minggu. Alat ukur ini merupakan skala yang banyak dipakai dalam penelitian epidemiologis mengenai tingkat gejala depresi di masyarakat umum. Contoh item dari skala CESD-R misalnya: "Saya kehilangan minat dalam kegiatan yang biasa saya lakukan sehari-hari" (subskala loss of interest/anhedonia), "Saya merasa seperti orang yang buruk" (subskala worthlessness), dan "Saya berharap untuk mati" (subskala suicidal ideation). Hasil uji coba menemukan bahwa untuk skala adaptasi CESD-R memiliki koefisien reliabilitas $\alpha=0.834$ dengan skor corrected item-total correlation sebesar $r=0.43-0.66$.

Skala resiliensi yang disusun oleh Connor \& Davidson (2003) mengukur tingkat resiliensi partisipan berdasarkan kombinasi dari lima dimensi meliputi: (1) kompetensi personal, standar yang tinggi dan keuletan, (2) percaya kepada diri sendiri, memiliki toleransi terhadap afek negatif dan kuat dalam menghadapi tekanan, (3) penerimaan positif terhadap perubahan dan hubungan yang baik dengan orang lain, (4) pengendalian diri, (5) pengaruh spiritual. Dari gabungan kelima dimensi tersebut diwakili oleh 25 aitem dengan lima pilihan jawaban 0-4 (sangat tidak benarhampir setiap kali benar). Skala ini sudah pernah diadaptasi sebelumnya oleh Listiyandini dan Akmal (2015) dan Permata dan Listiyandini (2015) pada sampel mahasiswa. Beberapa pernyataan item yang ada dalam skala resiliensi Connor dan Davidson misalnya: "Saya yakin dapat meraih tujuan" (aspek kompetensi personal), "Saya mampu untuk menyesuaikan diri terhadap perubahan" (aspek penerimaan terhadap perubahan), dan "Saya mampu membuat keputusan yang sulit" (aspek toleran terhadap afek negatif). Uji coba ulang menggunakan sampel remaja menemukan bahwa skala resiliensi Connor \& Davidson memiliki koefisien reliabilitas $\alpha=0.919$ dengan hasil corrected item-total correlation sebesar $r=0.28-0.78$.

Basic Empathy Scale (BES) adalah skala yang disusun oleh Jollife dan Farrington (2006) untuk mengukur empati pada remaja. Skala ini terdiri dari 20 aitem yang meliputi dua komponen empati, yaitu komponen afektif (11 aitem) dan kognitif (9 aitem) dengan skala likert yang terdiri dari lima pilihan jawaban dengan skala 1-5 dimulai dari "sangat tidak setuju" sampai dengan "sangat setuju". Contoh item dari skala adaptasi BES adalah: 'Ketika seseorang merasa 'terpuruk', saya biasanya bisa mengerti bagaimana perasaan mereka" (empati kognitif) atau "Saya tidak menjadi sedih ketika melihat orang lain menangis" (empati afektif). Selanjutnya, skala adaptasi BES ditemukan memiliki koefisien reliabilitas $\alpha=0.870$, dengan hasil corrected item-total correlation sebesar $r=0.2-0.57$. Bila mengacu pada standar kelayakan koefisien reliabilitas dan validitas dari Nisfianoor (2009), maka seluruh skala yang diadaptasi dapat dikategorikan reliabel dan layak untuk digunakan untuk pengambilan data.

\section{Analisis Data}

Untuk menjawab hipotesis penelitian, peneliti melakukan analisis statistik menggunakan teknik uji regresi sederhana dan regresi ganda melalui SPSS 21.0. Kedua jenis uji regresi dilakukan secara terpisah dengan tujuan untuk menjawab setiap hipotesis yang diajukan. Untuk hipotesis pertama, yaitu re- 
Igresi ganda melalui SPSS 21.0. Kedua jenis uji regresi dilakukan secara terpisah dengan tujuan untuk menjawab setiap hipotesis yang diajukan. Untuk hipotesis pertama, yaitu resiliensi berpengaruh signifikan terhadap gejala depresi dan hipotesis kedua, yaitu empati berpengaruh signifikan terhadap gejala depresi, menggunakan uji regresi sederhana. Sedangkan, uji regresi ganda dilakukan untuk membuktikan hipotesis ketiga, yaitu resiliensi dan empati secara bersama-sama berpengaruh terhadap depresi pada remaja serta uji tambahan untuk menganalisis seberapa besar pengaruh tiap komponen empati terhadap tingkat gejala depresi.

\section{Hasil}

Persebaran Skor Gejala Depresi, Resiliensi, Empati

Pengkategorian depresi dilakukan berdasarkan norma yang telah ada dalam alat ukur. Haroz, Ybarra, dan Eaton (2014) dalam alat ukur CESDR-10 mengkategorian depresi dengan cara melihat kehadiran simtom-simtom dari depresi pada tiap-tiap partisipan.
Semakin banyak simtom yang di munculkan subjek, semakin parah tingkat depresi yang dimilikinya. Pengkategorian depresi ini dimulai dari kategori depresi pada level yang tidak parah sampai level dengan tingkat keparahan klinis. Kategorisasi yang digunakan adalah major depressive episode, probable mayor depressive episode, possible major depressive episode, subthreshold depression symptoms dan no clinical significance.

Dari hasil analisis pada 230 remaja yang berpartisipasi dalam penelitian ini, ditemukan skor rata-rata tingkat gejala depresi sebesar $\mathrm{M}=8.61$ ( $\mathrm{SD}=6.1$ ). Dari hasil kategorisasi, sebanyak $50 \%$ partisipan digolongkan memiliki gejala depresi pada kategori no clinical significance. Namun demikian, terdapat persentase sebesar $40 \%$ untuk remaja yang masuk dalam kategori sub-threshold depression symptoms. Selanjutnya, untuk kategori possible major depressive episode sebesar $5.2 \%$, probable major depressive episode sebesar 3\%, dan major depressive episode sebesar $1.7 \%$. Berikut adalah tabel rangkuman mengenai kategorisasi tingkat gejala depresi pada partisipan:

Tabel 2. Gambaran Tingkat Gejala Depresi

\begin{tabular}{lll}
\hline Kategori & Total & Presentase \\
\hline Major depressive episode & 4 & $1,7 \%$ \\
Probable mayor depressive episode & 7 & $3,0 \%$ \\
Possible major depressive episode & 12 & $5,2 \%$ \\
Subthreshold depression symptoms & 92 & $40,0 \%$ \\
No clinical significance & 115 & $50,0 \%$ \\
Total & 230 & \\
\hline
\end{tabular}

Untuk variabel resiliensi, ditemukan skor rata-rata $M=70,53(S D=11,21)$. Apabila dilihat berdasarkan rentang skor ideal 0-100 dan dilakukan pengkategorian berdasarkan acuan dari Nisfianoor (2002), maka seba-

gian besar partisipan memiliki kategori resiliensi yang tergolong baik $(59,6 \%)$ dan sedang $(40,4 \%)$. Terlampir adalah tabel 3 yang menggambarkan kategorisasi tingkat resiliensi pada remaja:

Tabel 3. Kategorisasi Resiliensi

\begin{tabular}{llll}
\hline Kategori & Rentang Skor & Total & Presentase \\
\hline Rendah & $0-33$ & 0 & $0 \%$ \\
Sedang & $34-67$ & 93 & $40 \%$ \\
Tinggi & $68-100$ & 137 & $59,6 \%$ \\
& Total & 230 & \\
\hline
\end{tabular}


Untuk gambaran empati, ditemukan skor rata-rata $M=65,52(S D=7.50)$. Jika dibandingkan dengan rentang skor ideal dari 20-100, ditemukan bahwa sebagian besar remaja yang menjadi partisipan dalam peneli- tian ini memiliki empati pada kategori sedang $(80 \%)$, sedangkan $20 \%$ remaja pada kategori tinggi. Tabel 4 menggambarkan kategorisasi empati pada remaja:

Tabel 4. Kategorisasi Empati

\begin{tabular}{llll}
\hline Kategori & Rentang Skor & Total & Presentase \\
\hline Rendah & $20-46$ & 0 & $0 \%$ \\
Sedang & $47-73$ & 184 & $80 \%$ \\
Tinggi & $74-100$ & 46 & $20 \%$ \\
& Total & 230 & \\
\hline
\end{tabular}

Uji Normalitas dan Linearitas

Sebelum melakukan uji hipotesis, peneliti melakukan uji normalitas dan linearitas sebagai syarat dilakukannya uji regresi. Berdasarkan acuan dari Sugiyono (2013) mengenai hasil analisa uji normalitas dan linearitas, ditemukan bahwa persebaran data residual pengujian regresi tergolong normal $(p>0.05)$ dan hubungan antar variabel dikatakan linear $(p<0.05)$. Berikut adalah tabel 5 dan 6 yang menggambarkan hasil uji normalitas dan linearitas.

Resiliensi sebagai Prediktor Gejala Depresi Hasil analisis menemukan bahwa resiliensi berpengaruh terhadap tingkat ge- jala depresi pada remaja secara signifikan $(F=4.215, R 2=0.018, p<0.05)$. Oleh karena itu, hipotesis pertama dalam penelitian ini diterima. Selain itu, ditemukan juga bahwa besar pengaruh resiliensi terhadap depresi pada remaja adalah sebesar $1,8 \%$ sedangkan $98.2 \%$ lainnya dipengaruhi oleh faktor lain. Ditemukan juga nilai beta sebesar $\mathrm{B}=$ $-0.073(p<0.05)$. Hal tersebut menunjukkan bahwa setiap penambahan 1 angka pada variabel resiliensi maka akan terjadi penurunan skor depresi sebesar 0.073 dan penurunan ini ditemukan signifikan $(p<0.05)$. Berikut adalah tabel 5 yang menggambarkan hasil uji regresi resiliensi terhadap depresi.

Tabel 5. Model Regresi Sederhana Resiliesi sebagai Prediktor Depresi

\begin{tabular}{|c|c|c|c|c|c|c|c|c|}
\hline & A & B & $\beta$ & $\mathbf{F}$ & $\mathbf{R}$ & R2 & Adj. R2 & Sig \\
\hline & 13,78 & & & 4.215 & 0.135 & 0.018 & 0.014 & 0.041 \\
\hline SE (6.061) & & & & & & & & \\
\hline Resiliensi & & $-0,073^{*}$ & $-0,135$ & & & & & 0.041 \\
\hline
\end{tabular}

${ }^{*}$ Sig $p<0.05,{ }^{* *}$ Sig $p<0.01$

\section{Empati sebagai Prediktor Gejala Depresi}

Hasil uji hipotesis kedua menunjukkan bahwa empati mempengaruhi tingkat gejala depresi secara signifikan pada remaja $(F=4.604, R 2=0.020, p<0.05)$. Oleh karena itu, hipotesis kedua dalam penelitian ini diterima. Dalam hal ini, besar kontribusi empati dalam menjelaskan gejala depresi pada remaja sebesar $2 \%$, sedangkan $98 \%$ lainnya dipengaruhi oleh faktor lain. Nilai beta adalah sebesar $B=0.141 \quad(p<0.05)$, sehingga setiap penambahan 1 angka pada variabel empati maka akan terjadi peningkatan skor depresi sebesar 0.144 , dan peningkatan ini ditemukan signifikan $(p<0.05)$. Berikut adalah tabel 6 yang menggambarkan hasil uji regresi empati terhadap gejala depresi: 
Tabel 6. Model Regresi Sederhana Resiliesi sebagai Prediktor Depresi

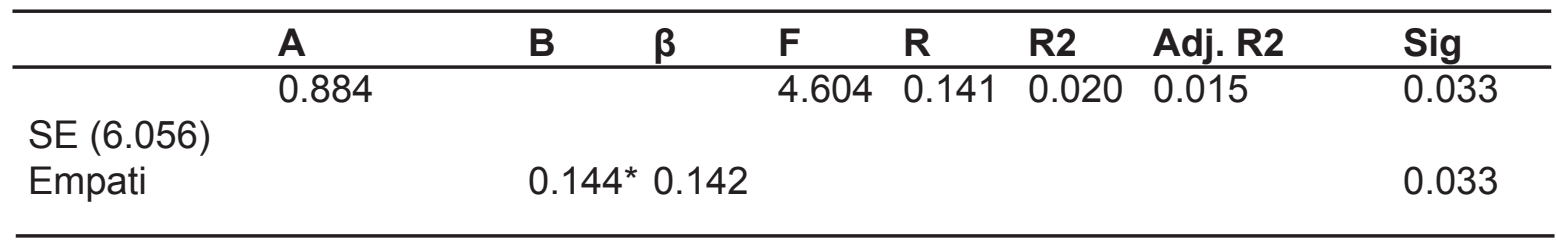

${ }^{*}$ Sig $p<0.05,{ }^{* *}$ Sig $p<0.01$

Pengujian lebih lanjut terkait dengan peran masing-masing aspek empati terhadap depresi menunjukkan bahwa hanya empati afektif yang berperan terhadap depresi pada remaja $(B=0.260, p<0.01)$. Untuk empati kognitif tidak ditemukan adanya kontribusi yang signifikan terhadap depresi $(p>0.05)$. Dengan kata lain, empati afektif dianggap lebih berperan terhadap peningkatan gejala depresi pada remaja, dibandingkan domain empati kognitif. Terlampir adalah tabel 7 yang menggambarkan hasil uji regresi dari setiap komponen empati terhadap gejala depresi:

Tabel 7. Model Regresi Empati Afektif dan Kognitif sebagai Prediktor Depresi

\begin{tabular}{lllll}
\hline & a & B & $\boldsymbol{\beta}$ & Sig \\
\hline (Constant) & 2.612 & & & 0.472 \\
Empati Afektif (X1) & & $0.260^{\star *}$ & 0.222 & 0.001 \\
Empati Kognitif (X2) & & -0.098 & -0.065 & 0.342 \\
\hline
\end{tabular}

${ }^{*}$ Sig $p<0.05,{ }^{* *}$ Sig $p<0.01$

Resiliensi dan Empati sebagai Prediktor Gejala Depresi Remaja

Hasil uji hipotesis ketiga menggunakan uji regresi berganda menunjukkan bahwa resiliensi dan empati secara bersama-sama berpengaruh signifikan terhadap gejala depresi pada remaja $(\mathrm{F}=6.648, \mathrm{R} 2=0.055$, $\mathrm{p}<0.01$ ), sehingga hipotesis ketiga dalam penelitian ini diterima. Kontribusi efektif variabel resiliensi dan empati secara bersama terhadap gejala depresi adalah sebesar $5.5 \%$ dan sisanya sebesar $94.5 \%$ dipengaruhi oleh faktor lain. Didapatkan pula nilai beta sebesar (B $=-0.108, p<0.01)$ untuk resiliensi. Hal tersebut menunjukkan bahwa setiap penambahan
1 angka pada variabel resiliensi, maka akan terjadi pengurangan skor depresi sebesar 0.108 dan pengurangan ini signifikan pada level $(p<0.01)$ Artinya, semakin tinggi besaran resiliensi, maka gejala depresi pada remaja semakin rendah. Berbeda halnya dengan empati, dari hasil pengujian mendapatkan nilai beta sebesar $(B=0.165, p<0.01)$. Hal tersebut menunjukkan bahwa setiap penambahan 1 angka pada empati, maka akan terjadi peningkatan skor depresi sebesar 0.165 yang signifikan pada level $p<0.01$. Berikut adalah tabel 8 rangkuman yang menjelaskan peran empati dan resiliensi secara bersama-sama terhadap gejala depresi:

Tabel 8. Model Regresi Sederhana Resiliesi sebagai Prediktor Depresi

\begin{tabular}{|c|c|c|c|c|c|c|c|c|}
\hline & A & B & $\beta$ & $F$ & $\mathbf{R}$ & R2 & Adj. R2 & Sig \\
\hline & 5,076 & & & 6.648 & 0.235 & 0.055 & 0.047 & 0.188 \\
\hline SE (5.958) & & & & & & & & \\
\hline Resiliensi & & $-0.108^{*}$ & -0.199 & & & & & 0.004 \\
\hline Empati & & $0.165^{*}$ & 0.203 & & & & & 0.003 \\
\hline
\end{tabular}

${ }^{*}$ Sig $p<0.05,{ }^{* *}$ Sig $p<0.01$ 
Pengujian lanjutan dengan uji semiparsial dilakukan untuk melihat kontribusi peranan murni dari masing-masing variabel, yakni resiliensi, empati afektif, dan empati kognitif terhadap tingkat gejala depresi pada remaja. Uji korelasi semi parsial didapatkan bahwa resiliensi dan empati afektif memiliki pengaruh signifikan terhadap depresi, dimana variabel empati afektif menghasilkan peran sebesar $4.4 \% \quad\left(s r^{2}=0.044, p<0.01\right)$, empati kognitif tidak berperan terhadap gejala depresi, dan resiliensi berperan sebesar $2.3 \%\left(\mathrm{sr}^{2}=0.023\right.$, $\mathrm{p}<0.05)$,. Berikut adalah tabel 9 rangkuman hasil uji statistik dengan uji semi parsial.

\section{Tabel 9. Korelasi Semi-Parsial Resiliensi, Empati Afektif, dan Empati Kognitif, dengan Gejala Depresi}

\begin{tabular}{llll}
\hline & & sr $^{\mathbf{2}}$ & sig \\
\hline 1 & Gejala Depresi & - & \\
2 & Resiliensi & $0.023^{* *}$ & 0.019 \\
3 & Empati Afektif & $0.044^{* *}$ & 0.001 \\
4 & Empati Kognitif & 0.00 & 0.985 \\
\hline
\end{tabular}

${ }^{*}$ Sig $p<0.05,{ }^{* *}$ Sig $p<0.01$

Uji Perbedaan Empati, Resiliensi, dan Depresi berdasarkan Faktor Demografis

Hasil uji tambahan ditemukan bahwa usia berhubungan dengan tingkat resiliensi remaja $(r=0.178, p<0.01)$. Selain itu, uji tambahan terkait faktor demografis yang mempengaruhi empati, ditemukan bahwa terdapat perbedaan empati remaja secara signifikan apabila ditinjau dari jenis kelamin $(t=-8.026$, $p<0,000$ ) dengan perbedaan perempuan memiliki skor rata-rata lebih besar $(M=70.65)$ dibanding laki-laki $(\mathrm{M}=63.62)$. Terdapat pula perbedaan depresi remaja secara signifikan apabila ditinjau dari jenis kelamin $(t=-2.237$, $p<0.05)$, dimana perempuan memiliki skor rata-rata lebih besar $(M=9.39)$ dibanding lakilaki $(\mathrm{M}=7.62)$.

\section{Pembahasan}

Depresi merupakan salah satu gangguan mood (suasana perasaan) (Nevid, Rathus \& Greene, 2005; Oltmanns \& Emery, 2013) yang serius dan sering terjadi pada remaja (Papalia, Olds, \& Feldman, 2009; Utari \& Retnowati, 2011; Hashmi, 2013). Berdasarkan hasil analisis yang dilakukan dalam penelitian ini, ditemukan bahwa resiliensi berpengaruh terhadap gejala depresi pada remaja dengan sumbangan efektif sebesar $1,8 \%$, yaitu peningkatan resiliensi akan diikuti dengan semakin rendahnya gejala depresi.
Hasil penelitian ini mendukung temuan sebelumnya yang dilakukan oleh Ziaian, et.al. (2012) yang menunjukkan bahwa resiliensi menjadi prediktor terhadap tingkat keparahan depresi remaja. Peran resiliensi terhadap depresi ini dikarenakan resiliensi dapat menjadi faktor pelindung bagi remaja untuk tidak mengalami faktor risiko seperti depresi (Masten \& Coatsworth, 1998; Zautra, Hall, \& Murray, 2010).

Berdasarkan temuan Schure, Odden dan Goins (2013), individu dengan resiliensi tinggi lebih memungkinkan untuk mengalami emosi positif. Emosi positif yang dimiliki akan membantu remaja untuk mengurangi emosi negatif sehingga remaja tetap dapat berfungsi secara optimal walaupun dihadapkan pada suatu tantangan dalam mencapai tugas perkembangannya (Bonanno, 2004). Dalam hal kognitif, remaja dengan resiliensi yang baik mampu menunjukkan fleksibilitas dalam berfikir, sehingga ketika dihadapkan dengan tuntutan perubahan ataupun permasalahan, ia tidak terpaku pada permasalahannya, cepat dalam melakukan coping stres dan dapat memikirkan alternatif-alternatif penyelesaian masalah yang sedang ia alami (Block \& Kreman 1996; Fredrickson \& Levenson 1998; Luthar, Cicchetti, \& Becker, 2000; Tugade dan Fredrickson 2004).

Selanjutnya, hasil penelitian juga menunjukkan bahwa empati berpengaruh 
dalam menjelaskan gejala depresi pada remaja sebesar $2 \%$, yaitu tingginya empati remaja diikuti dengan meningkatnya depresi. Analisa lebih lanjut menemukan bahwa komponen empati yang dianggap memiliki kontribusi signifikan dalam peningkatan gejala depresi pada remaja $(p<0.01)$ adalam komponen empati afektif dibandingkan empati kognitif. Empati afektif merupakan komponen empati yang menggambarkan sejauh mana individu dapat merasakan respon emosi yang selaras sesuai dengan kondisi emosi yang dirasakan orang lain (Decety \& Jackson, 2004). Oleh karena itu, remaja dengan empati afektif yang tinggi, cenderung mudah untuk ikut merasakan kesedihan, kemarahan, penderitaan, maupun kebahagiaan orang lain. Penelitian sebelumnya menemukan bahwa empati berhubungan negatif dengan depresi pada kedua aspek dari empati, yaitu aspek afektif dan kognitif (Cusi, MacQueen, Spreng \& McKinnon, 2011) atau penelitian yang menemukan bahwa depresi terkait dengan aspek kognitif, yaitu perspective taking dan tidak terkait dengan aspek afektif (Schreiter, Pijnenborga, \& Rota, 2013). Oleh karena itu, hasil dalam penelitian ini yang menemukan bahwa empati afektif berpengaruh untuk memunculkan gejala depresi yang lebih tinggi menjadi temuan baru dibandingkan penelitian sebelumnya.

Berdasarkan studi literatur, peran empati afektif terhadap tingginya depresi pada remaja diduga berkaitan dengan adanya proses regulasi emosi yang masih belum berkembang baik pada remaja. Terkait dengan perkembangan emosi remaja, pada masa ini, remaja dilaporkan seringkali mengalami suasana emosi yang negatif dan juga adanya naik turun dalam keadaan emosional, sehingga remaja sering dikatakan belum memiliki kemampuan regulasi emosi yang baik (Rosenblum \& Lewis, 2006; Larson \& Brown, 2007; Crowell, Skidmore, Rau, \& Williams, 2013). Kemampuan regulasi emosi yang belum berkembang baik diduga mempengaruhi reaksi remaja dalam memproses emosi yang dimilikinya, termasuk dalam menanggapi reaksi emosi orang lain di sekitarnya.

Ketika remaja dihadapkan dengan situasi yang menimbulkan stres, seperti per- asaan-perasaan negatif orang lain, dapat terjadi penularan emosi negatif dan munculnya rasa sakit bersama dengan orang lain (Shamay-Tsoory dalam Schreiter, Pijnenborga, \& Rota, 2013). Hal tersebut dapat membuat remaja gagal dalam membedakan antara perasaan dirinya dan perasaan orang lain, yang pada akhirnya, empati tersebut justru meningkatkan tekanan dalam diri secara pribadi (Batson, 1991).

Kemampuan regulasi emosi yang masih belum berkembang baik maupun kegagalan dalam membedakan perasaan dirinya dan perasaan orang lain justru mengakibatkan empati afektif yang muncul lebih dominan memunculkan personal distress (Batson, 1991; Decety, 2010). Personal distress adalah salah satu aspek empati afektif yang sering juga diasosiasikan dengan kemunculan emosi negatif seperti depresi (Davis, 1983). Personal distress mencerminkan kapasitas seseorang untuk mengalami emosi negatif saat melihat penderitaan orang lain (Neumann, Chan, Wang, \& Boyle, 2016). Personal distress membuat individu mengubah fokus mereka ke dalam dirinya dengan memfokuskan perhatian mereka pada emosi serta meringankan kecemasan diri sendiri yang ditimbulkan akibat melihat penderitaan orang lain (Cassels, Chan, Chung, \& Birch, 2010).

Penelitian menunjukkan adanya hubungan yang positif antara depresi dan personal distress dari empati afektif, dimana adanya respon empati yang terlalu berorientasi pada diri dapat meningkatkan depresi pada seseorang (O'Connor, Berry, \& Weiss, 2002; Ghorbani dalam Schreiter, Pijnenborga, \& Rota, 2013). Adanya personal distress membuat remaja terlarut pada perasaan negatif orang lain di sekitarnya, dan lebih mengarah kepada diri sendiri, sehingga membuat mereka lebih rentan mengalami depresi.

Hasil penelitian juga menunjukkan bahwa resiliensi dan empati secara bersamasama berpengaruh terhadap depresi pada remaja dengan kontribusi sebesar $5,5 \%$. Berdasarkan hasil analisis menunjukkan tingginya resiliensi, diikuti dengan rendahnya depresi pada remaja, sedangkan tingginya empati, khususnya empati afektif menun- 
jukkan tingginya kemunculan depresi pada remaja. Apabila melihat arah hubungannya ketika variabel resiliensi dimasukan hubungannya dengan variabel depresi, peneliti memprediksi bahwa pengaruh empati afektif dalam meningkatkan depresi pada remaja dapat berkurang dengan adanya resiliensi. Dengan adanya resiliensi, remaja akan mampu mengendalikan perasaan (Grotberg, 1995), serta meregulasi emosi yang muncul ketika dihadapkan dalam emosi negatif (Reivich \& Shatte, 2002). Dengan adanya regulasi emosi yang berhubungan dengan resiliensi, remaja dapat menyeimbangkan emosi yang dialaminya (Thompson, 1991), sehingga hal ini dapat membantunya untuk tidak mengalami perasaan terlarut dalam emosi orang lain atau personal distess dari empati afektif dan pada akhirnya mencegah kemunculan depresi. Hasil temuan bahwa empati afektif berperan terhadap tingginya gejala depresi menjadi temuan baru yang perlu ditelaah lebih lanjut dan dibuktikan kembali pada penelitian-penelitian selanjutnya.

Resiliensi dan empati secara bersamasama hanya berperan sebesar $5,5 \%$ terhadap depresi remaja, sehingga terdapat beberapa faktor lain yang diduga mempengaruhi gejala depresi namun belum diukur dalam penelitian ini, seperti faktor genetik, faktor neurologis dan hormonal, kepribadian, peristiwa negatif kehidupan, kemampuan coping, dan faktor pelindung lain seperti konsep diri, harga diri, dukungan keluarga, serta faktor lingkungan (Herman, et.al. 2009; Ranttila \& Shrestha, 2011).

Hasil uji tambahan terkait faktor demografi terhadap resiliensi, ditemukan bahwa usia berhubungan dengan tingkat resiliensi remaja. Hasil ini serupa dengan penelitian yang dilakukan Sun dan Stewart (2007) yang menunjukkan bahwa usia berpengaruh terhadap resiliensi seseorang. Semakin matang usia individu, semakin ia mampu untuk memandang suatu masalah secara lebih positif sehingga memungkinkannya untuk lebih resilien.

Untuk uji tambahan terkait faktor demografis yang mempengaruhi empati, ditemukan bahwa terdapat perbedaan empati remaja secara signifikan apabila ditinjau dari jenis kelamin dengan perbedaan perempuan memiliki skor rata-rata lebih besar dibanding laki-laki. Hasil tersebut sejalan dengan penelitian yang dilakukan Buck (1995) yang menunjukkan bahwa perempuan memiliki empati yang lebih tinggi dibanding laki-laki, terlebih pada komponen empati afektif (Lafferty dalam Garaigordobil, 2009).

Mengingat bahwa hasil utama dalam penelitian ini menemukan adanya asosiasi positif antara empati dan gejala depresi, maka tingginya skor empati pada perempuan yang ditemukan dalam penelitian, diduga dapat menjelaskan faktor perbedaan gender dalam gejala depresi yang selama ini ditemukan dalam penelitian sebelumnya (Wade, Cairney, \& Pevalin, 2002; Galambos, Leadbeater, Barker, 2004; Helgeson, 2012). Konsisten dengan penelitian sebelumnya, bahwa dalam penelitian ini ditemukan bahwa terdapat perbedaan depresi remaja secara signifikan apabila ditinjau dari jenis kelamin, dimana perempuan memiliki kemunculan gejala depresi lebih tinggi dibandingkan lakilaki. Temuan ini sejalan dengan penelitian sebelumnya yang menunjukkan bahwa remaja perempuan memiliki faktor risiko lebih untuk mengalami depresi daripada remaja laki-laki (Nolen-Hoeksema \& Girgus, dalam Children's Mental Health Ontario, 2001). Dalam hal ini, tingginya skor empati yang dimiliki remaja perempuan diduga memprediksi tingkat depresi yang lebih tinggi pula. Asumsi ini perlu ditelaah lebih lanjut dalam penelitian lainnya.

Peneliti menyadari masih terdapatnya kelemahan ataupun kekurangan pada proses penelitian yang dilakukan, diantaranya, alat ukur yang digunakan peneliti dalam mengukur empati tidak secara spesifik mengukur mengenai personal distress dalam aspek empati afektif dan tidak mengukur regulasi emosi yang diduga mempengaruhi kemunculan tingkat depresi seseorang. Selain itu, sampel yang digunakan masih menggunakan remaja umum sehingga tidak dapat dijadikan acuan untuk menggambarkan kondisi depresi remaja pada populasi khusus yang memang sudah memiliki riwayat depresi ataupun remaja yang secara khusus lebih rentan mengalami depre- 
si, misalnya pada mahasiswa, remaja yang kehilangan orangtua, mengalami perceraian, dan sebagainya.

\section{Kesimpulan}

Berdasarkan hasil penelitian ini ditemukan bahwa resiliensi berpengaruh signifikan dalam menjelaskan gejala depresi remaja dengan sumbangan efektif sebesar $1.8 \%$. Dalam hal ini, penambahan skor resiliensi akan diikuti dengan penurunan skor gejala depresi. Penelitian ini juga menemukan bahwa empati, khususnya domain empati afektif, berpengaruh secara signifikan dalam menjelaskan gejala depresi pada remaja dengan kontribusi efektif sebesar $2 \%$. Ditemukan bahwa semakin tinggi empati afektif pada remaja, maka semakin tinggi pula kemungkinan munculnya gejala depresi pada mereka.

Secara bersama, resiliensi dan empati, khususnya empati afektif, berpengaruh signifikan terhadap tingkat gejala depresi pada remajadengan kontribusi efektif sebesar $5.5 \%$. Dalam hal ini, empati afektif berpengaruh pada munculnya gejala depresi yang lebih tinggi. Namun sebaliknya, resiliensi berpengaruh pada menurunnya gejala depresi. Hasil ini mengindikasikan bahwa pengaruh empati afektif yang dapat meningkatkan terjadinya gejala depresi diprediksi akan berkurang jika terdapat resiliensi yang tinggi.

Secara metodologis, diharapkan penelitian selanjutnya dapat menggunakan alat ukur lain yang lebih dapat mengukur aspek personal distress dalam empati afektif. Hal ini terkait dengan keterbatasan penelitian yang sudah dijelaskan dalam pembahasan bahwa skala yang digunakan peneliti dalam mengukur empati belum secara spesifik mengukur mengenai personal distress dalam aspek empati afektif. Penelitian selanjutnya juga diharapkan melibatkan variabel psikologis lain, yaitu regulasi emosi yang diduga berperan terhadap kemunculan depresi ataupun faktor lain yang diduga berpengaruh terhadap depresi, serta melakukan penelitian dengan desain longitudinal. Sebagai implikasi dari hasil penelitian, maka dalam intervensi untuk mencegah atau mengatasi gejala depresi pada remaja, diperlukan adanya perhatian pada aspek empati dan resiliensi yang dimiliki remaja.

\section{Daftar Pustaka}

Aditomo, A., \& Retnowati, S. (2004). Perfeksionisme, harga diri, dan kecenderungan depresi pada remaja akhir. Jurnal psikologi, 31(1), 1-14.

American Psychiatric Association. (2013). DSM-V: Diagnostic and statistical manual of mental disorders (5th ed., Text Revision). Washington, DC

Anindyajati, P. D. (2013). Status identitas remaja akhir: hubungannya dengan gaya pengasuhan orangtua dan tingkat kenakalan remaja. Character: Jurnal Penelitian Psikologi., 1(2). 1-6.

Andriani, A., \& Listiyandini, R. A. (2017). Peran kecerdasan sosial terhadap resiliensi pada mahasiswa tingkat awal. Psympathic: Jurnal IImiah Psikologi, 4(1), 67-90.

Arnett, J. J. (1999). Adolescent storm and stress, reconsidered. American psychologist, 54(5), 317.

Badan Pusat Statistik. (2017). Jumlah penduduk dan laju pertumbuhan penduduk. Diunduh dari web: http:// www.jakarta.bps.go.id pada tanggal 21 April 2018.

Baron-Cohen, S., \& Wheelwright, S. (2004). The empathy quotient: an investigation of adults with Asperger syndrome or high functioning autism, and normal sex differences. Journal of autism and developmental disorders, 34(2), 163-175.

Batson, C. (1991). The altruism question: toward a social-psychological answer. Lawrence Erlbaum Associates: Hillsdale, New Jersey.

Batubara, J. R. (2016). Adolescent development (perkembangan remaja). Sari Pediatri, 12(1), 21-9.

Bitsika, V., Sharpley, C. F., \& Peters, K. (2010). How is resilience associated with anxiety and depression? Analysis of 
factor score interactions within a homogeneous sample. German journal of psychiatry, 13(1), 9-16.

Block, J., \& Kremen, A. M. (1996). IQ and ego-resiliency: conceptual and empirical connections and separateness. Journal of personality and social psychology, 70(2), 349.

Bonanno, G. A. (2004). Loss, trauma, and human resilience: have we underestimated the human capacity to thrive after extremely aversive events?. American psychologist, 59(1), 20.

Camardese, G., Janiri, L., Leone, B., Mattioli, B., Serrani, R., \& Treglia, M. (2012). Childhood trauma, resilience and depression. International Journal of Psychiatry in Clinical practice, 16(1), 52-53.

Cassels, T. G., Chan, S., \& Chung, W. (2010). The role of culture in affective empathy: Cultural and bicultural differences. Journal of Cognition and Culture, 10(3), 309-326.

Children's Mental Health Ontario. (2001). Evidence Based Practices for Depression in Children and Adolescents, diunduh dari http:// www.cmho.org pada Mei 2017.

Choudhury, S., Blakemore, S. J., \& Charman, T. (2006). Social cognitive development during adolescence. Social cognitive and affective neuroscience, 1(3), 165-174.

Chow, C. M., Ruhl, H., \& Buhrmester, D. (2013). The mediating role of interpersonal competence between adolescents' empathy and friendship quality: A dyadic approach. Journal of Adolescence, 36(1), 191-200.

Connor, K.M., \& Davidson, M.D. (2003). Development of a new resilience scale: The Connor-Davidson Resilience Scale (CD-RISC). Depression and Anxiety, 18, 76-82.

Crowell, S. E., Skidmore, C. R., Rau, H. K., \& Williams, P. G. (2013). Psychosocial stress, emotion regulation, and resilience in adolescence. In Handbook of adolescent health psychology (pp. 129-141). Springer: New York. Crump, C., Sundquist, J., Winkleby, M. A., \& Sundquist, K. (2016). Low stress resilience in late adolescence and risk of hypertension in adulthood. Heart, doi:10.1136/ heartjnl-2015308597.

Cusi, A. M., MacQueen, G. M., Spreng, R. N., \& McKinnon, M. C. (2011). Altered empathic responding in major depressive disorder: relation to symptom severity, illness burden, and psychosocial outcome. Psychiatry research, 188(2), 231-236.

Davis, M. H. (1983). Measuring individual differences in empathy: Evidence for a multidimensional approach. Journal of personality and social psychology, 44 (1), 113.

Decety, J. (2010). The neurodevelopment of empathy in humans. Developmental neuroscience, 32(4), 257-267.

Decety, J., \& Jackson, P. L. (2004). The functional architecture of human empathy. Behavioral and cognitive neuroscience reviews, 3(2), 71-100.

Dixon, J. A., \& Moore, C. F. (1990). The development of perspective taking: Understanding differences in information and weighting. Child Development, 61(5), 1502-1513.

Donges, U. S., Kersting, A., Dannlowski, U., Lalee-Mentzel, J., Arolt, V., \& Suslow, T. (2005). Reduced awareness of others' emotions in unipolar depressed patients. The Journal of nervous and mental disease, 193(5), 331-337.

Egbert, N., Miraldi, L. B., \& Murniadi, K. (2014). Friends don't let friends suffer from depression: How threat, efficacy, knowledge, and empathy relate to college students'; intentions to intervene on behalf of a depressed friend. Journal of health communication, 19(4), 460-477.

Eisenberg, N. (2000). Emotion, regulation, and moral development. Annual 
review of psychology, 51(1), 665-697.

Everall, R. D., Altrows, K. J., \& Paulson, B. L. (2006). Creating a future: A study of resilience in suicidal female adolescents. Journal of Counseling \& Development, 84(4), 461-470.

Fredrickson, B. L., \& Levenson, R. W. (1998). Positive emotions speed recovery from the cardiovascular sequelae of negative emotions. Cognition \& emotion, 12(2), 191.

Galambos, N. L., Leadbeater, B. L., \& Barker, E. T. (2004). Gender differences in and risk factors for depression in adolescence: A 4-year longitudinal study. International Journal of Behavioral Development, 28 (1), 16-25.

Garaigordobil, M. (2009). A comparative analysis of empathy in childhood and adolescence: Gender differences and associated socio-emotional variables. International Journal of Psychology and psychological therapy, 9(2), 217235

Grotberg, E. (1995). A Guide to Promoting Resilience in Children: Strengthening The Human Spirit. USA: Benard Van Leer Fondation.

Hashmi, S. A. B. A. (2013). Adolescence: An age of storm and stress. Review of Arts and Humanities, 2(1).

Haroz, E. E., Ybarra, M., \& Eaton, W. W. (2014). Psychometric evaluation of a self-report scale to measure adolescent depression: the CESDR-10 in two national adolescent samples in the United States. Journal Affect Disorder, 158, 154-160.

Helgeson, V.S. (2012). The Psychology of Gender. 4th ed. United State: Pearson Education, Inc

Herman, K.C.; Reinke, W.M.; Parkin, J; Traylor, K.B. \& Agarwal, G. (2009). Childhood depression: rethinking the role of the school. Psychology in the School, 45 (5), 433-443

Hilt, L., Hanson, J., \& Pollak, S. (2011). Emotion Dysregulation. In B. Bradford Brown, \& M. Prinstein, Encyclopedia of Adolescence, Volume 3 (pp. 160-169). Elsevier Inc: New York. Hjemdal, O., Vogel, P. A., Solem, S., Hagen, K., \& Stiles, T. C. (2011). The relationship between resilience and levels of anxiety, depression, and obsessive-compulsive symptoms in adolescents. Clinical psychology \& psychotherapy, 18(4), 314-321

Jolliffe, D., \& Farrington, D. P. (2006). Development and validation of the Basic Empathy Scale. Journal of adolescence, 29(4), 589-611.

Keenan, K. \& Hipwell, A. E. (2005). Preadolescent clues to understanding depression in girls. Clinical Child and Family Psychology Review, 8(2), 89105

Kenny, R., Dooley, B., \& Fitzgerald, A. (2013). Interpersonal relationships and emotional distress in adolescence. Journal of Adolescence, 36(2), 351360

Kessler, R.C., Avenevoli, S., \& Merikangas, K. R. (2001). Mood disorders in children and adolescents: An epidemiologic perspective. Biological Psychiatry, 49:1002-1014

Larson, R. W., \& Brown, J. R. (2007). Emotional development in adolescence: What can be learned from a high school theater program? Child Development, 78 (4), 10831099

Listyandini, R. A., \& Akmal, S. A. (2015). Hubungan antara kekuatan karakter dan resiliensi pada mahasiswa. Prosiding Temu IImiah Nasional Psikologi. Jakarta: Fakultas Psikologi Universitas Pancasila

Loh, J. M., Schutte, N. S., \& Thorsteinsson, E. B. (2014). Be happy: The role of resilience between characteristic affect and symptoms of depression. Journal of Happiness Studies, 15 (5), 1125-1138

Luthar, S. S., Cicchetti, D., \& Becker, B. (2000). The construct of resilience: A critical evaluation and guidelines for future work. Child 
Development, 71(3), 543-562.

Masten, A. S., \& Coatsworth, J. D. (1998). The development of competence in favorable and unfavorable environments: Lessons from research on successful children. American psychologist, 53(2), 205-220

Milin, R., Walker, S., \& Chow, J. (2003). Major depressive disorder in adolescence: A brief review of the recent treatment literature. The Canadian Journal of Psychiatry, 48(9), 600-606.

Neumann, D. L., Chan, R. C., Wang, Y., \& Boyle, G. J. (2016). Cognitive and affective components of empathy and their relationship with personality dimensions in a Chinese sample. Asian Journal of Social Psychology, 19 (3), 244-253.

Nevid, J. S., Rathus, S. A., \& Greene, B. (2005). Psikologi Abnormal. Jakarta: Erlangga

Nisfianoor, M. (2009). Pendekatan Statistika Modern IImu Sosial. Jakarta: Salemba Humanika

O'Connor, L. E., Berry, J. W., Weiss, J., \& Gilbert, P. (2002). Guilt, fear, submission, and empathy in depression. Journal of affective disorders, 71(1), 19-27.

Oltmanns, T. F., \& Emery, R. E. (2013). Psikologi Abnormal. 7th ed. Yogyakarta: Pustaka Pelajar.

Papalia, E. D., Olds, W. S., \& Feldman, D. R. (2009). Perkembangan Manusia. Buku 2, Edisi 10. Jakarta: Salemba Humanika

Permata, D. C., \& Listiyandini, R. A. (2015). Peranan pola asuh orang tua dalam memprediksi resiliensi mahasiswa tahun pertama yang merantau di jakarta. Prosiding PESAT, 6.

Pinquart, M. (2009). Moderating effects of dispositional resilience on associations between hassles and psychological distress. Journal of applied Developmental psychology, 30 (1), 53-60

Reivich, K., \& Shatte, A. (2002).The Resil- ience factor: 7 Essential skills or overcoming life in evitable obstacles. New York: Broadway Books

Retnowati, S. (2001). Remaja dan Permasalahannya. Yogyakarta: Universitas Gajah Mada

Rosenblum, G. D., \& Lewis, M. (2006). Emotional development in adolescence. Blackwell Handbook of Adolescence. Blackwell Publishing Ltd

Balitbang Kementrian Kesehatan. (2013). Laporan Riskesdas 2013 dalam Angka. Diunduh dari www.depkes. go.id pada tanggal 21 April 2018.

Schreiter, S., Pijnenborg, G. H. M., \& Aan Het Rot, M. (2013). Empathy in adults with clinical or subclinical depressive symptoms. Journal of Affective Disorders, 150(1), 1-16.

Schure, M. B., Odden, M., \& Goins, R. T. (2013). The association of resilience with mental and physical health among older American Indians: The native elder care study. American Indian and Alaska native mental health research (Online), 20(2), 27.

Shaffer, R. David., Katherine, K., Elleen, W. \& Willoughby, T. (2013). Developmental Psychology Childhood and Adolescence. United States: Nelson Education Ltd.

Son, S. E., \& Kirchner, J. T. (2000). Depression in children and adolescents. American family physician, 62(10), 2297-308.

Steinberg, L. (2009). Adolescent development and juvenile justice. Annual review of clinical psychology, 5, 459-485.

Sugiyono. (2013). Statistika untuk Penelitian. Bandung: Alfabeta

Sun, J., \& Stewart, D. (2007). Age and gender effects on resilience in children and adolescents. International Journal of mental health promotion, 9(4), 16-25.

Smith, R. L., \& Rose, A. J. (2011). The "cost of caring" in youths' friendships: Considering associations among social perspective taking, co-rumina tion, and empathetic distress. 
Developmental psychology, 47 (6) 1792

Thompson, R. A. (1991). Emotional regulation and emotional development. Educational Psychology Review. 3(4), 269-307

Thorsteinsson, E. B., Ryan, S., \& Sveinbjornsdottir, S. (2013). The mediating effects of social support and coping on the stress-depression relationship in rural and urban adolescents. Open Journal of Depression, 2(1), 1-6.

Tugade, M. M., \& Fredrickson, B. L. (2004). Resilient individuals use positive emotions to bounce back from negative emotional experiences. Journal of personality and social psychology, 86(2), 320.

Utari, H. \& Retnowati, S. (2011). "Makro" program: a way to minimize depressive symptoms in teenagers. Anima: Psychological Indonesian Journal, 27 (1), 1-15

Wade, T. J., Cairney, J., \& Pevalin, D. J. (2002). Emergence of gender differences in depression during adolescence: National panel results from three countries. Journal of the American Academy of Child \& Adolescent Psychiatry, 41 (2), 190198.

Wilks, S. E. (2008). Psychometric evaluation of the shortened resilience scale among Alzheimer's caregivers. American Journal of Alzheimer's Disease \& Other Dementias $®, 23$ (2), 143-149.

Zautra, A. J., Hall, J. S., \& Murray, K. E. (2010). Resilience: A new definition of health for people and communities. In J. W. Reich, A. J. Zautra, \& J. S. Hall (Eds.), Handbook of adult resilience. New York: Guilford.

Ziaian, T., de Anstiss, H., Antoniou, G., Baghurst, P., \& Sawyer, M. (2012).

Resilience and its association with depression, emotional and behavioural problems, and mental health service utilisation among refugee adolescents living in South Australia. International Journal of Population Research, 2012. 